$\frac{5}{1119} 19550(2)$

/

ENERGY MEASUREMENTS

\title{
AN AERIAL RADIOLOGICAL SURVEY OF THE WRIGHT-PATTERSON AIR FORCE BASE AND SURROUNDING AREA
}

FAIRBORN, OHIO

DATE OF SURVEY: JULY 7-20, 1994
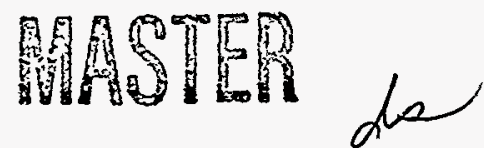

DISTRIBUTION OF THIS DOCUMENT IS UNLIMITED 


\section{DISCLAIMER}

This report was prepared as an account of work sponsored by an agency of the United States Government. Neither the United States Government nor any agency thereof, nor any of their employees, makes any warranty, express or implied, or assumes any legal liability or responsibility for the accuracy, completeness, or usefulness of any information, apparatus, product, or process disclosed, or represents that its use would not infringe privately owned rights. Reference herein to any specific commercial product, process, or service by trade name, trademark, manufacturer, or otherwise, does not necessarily constitute or imply its endorsement, recommendation, or favoring by the United States Government or any agency thereof. The views and opinions of authors expressed herein do not necessarily state or reflect those of the United States Government or any agency thereof.

This report has been reproduced directly from the best available copy.

Available to DOE and DOE contractors from the Office of Scientific and Technical Information, P.O. Box 62, Oak Ridge, Tennessee 37831; prices available from (615) 576-8401.

Available to the public from the National Technical Information Service, U.S. Department of Commerce, 5285 Port Royal, Springfield, Virginia 22161. 


\begin{abstract}
An aerial radiological survey was conducted over areas of Wright-Patterson Air Force Base (WPAFB) and the immediate surrounding area, during the period July 7 through 20,1994 . The survey was conducted to measure and map the gamma radiation in the area. This mission was the first aerial radiation survey conducted at WPAFB.

In the surveyed area, five small localized sources of gamma radiation were detected which were atypical of naturally-occurring radionuclides. On WPAFB property, these sources included a radiation storage facility in Area $B$ (krypton-85) and an ash pile near the Area C flight line (low energy gamma activity). In the area covered outside WPAFB boundaries, sources included cesium- 137 in excess of worldwide fallout over a landfill in a northern Dayton industrial area, an X-ray radiography source over a steel plant in the same industrial area, and a mixture of cesium-137 in excess of worldwide fallout and possibly iridium-192 in an area near Crystal Lakes, Ohio.

The naturally-occurring gamma emitters (uranium-238 and progeny, thorium and progeny, and potassium-40) were detected in the remaining area with a total exposure rate range of 4 to $16 \mu \mathrm{R} / \mathrm{h}$; this range is typical of that found in the United States, 1 to $20 \mu \mathrm{R} / \mathrm{h}$.
\end{abstract}




\title{
AN AERIAL RADIOLOGICAL SURVEY OF THE WRIGHT-PATTERSON AIR FORCE BASE AND SURROUNDING AREA
}

\author{
FAIRBORN, OHIO
}

DATE OF SURVEY: JULY 7-20, 1994

E. L. Feimster

Project Scientist



Radiation Science Section

This Document is UNCLASSIFIED

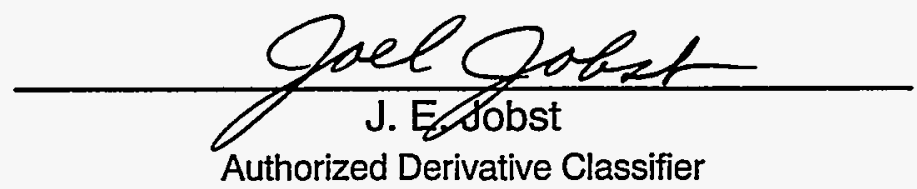

This work was performed by EG\&G/EM for the United States Department of Energy and the United States Department of Défense under Contract Number DE-AC08-93NV11265. 


\section{CONTENTS}



\section{Sections}







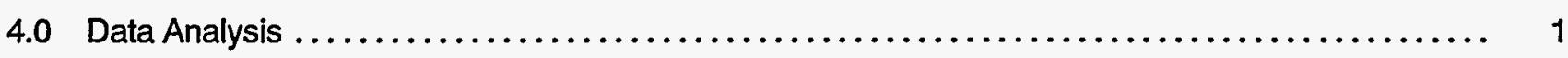

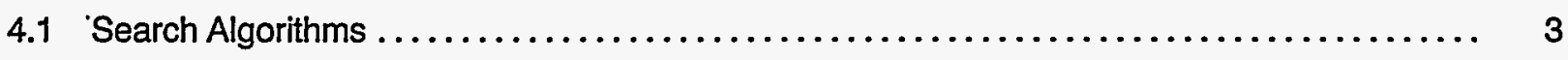

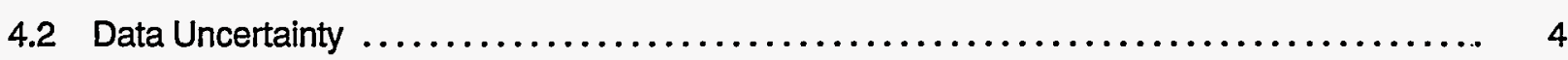

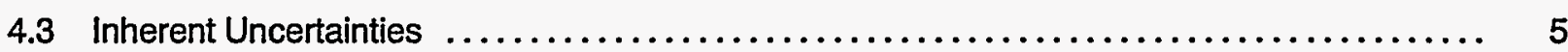

4.4 Large-Area Averaging of the Detector System $\ldots \ldots \ldots \ldots \ldots \ldots \ldots \ldots \ldots \ldots \ldots \ldots \ldots \ldots \ldots \ldots \ldots \ldots \ldots \ldots$

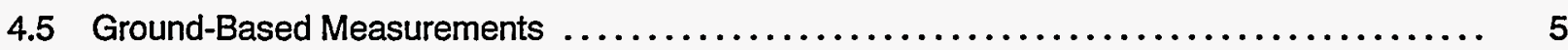

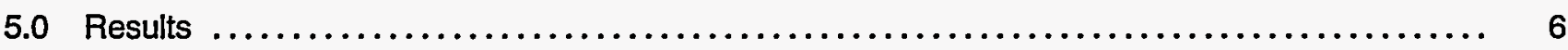

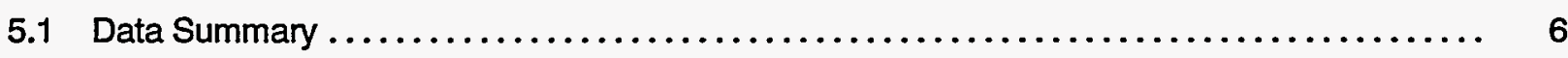

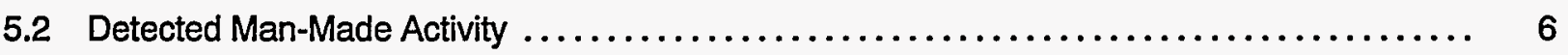

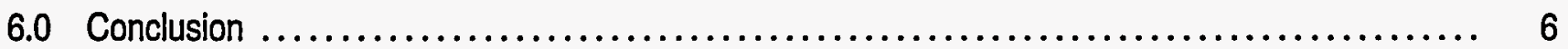

\section{Figures}

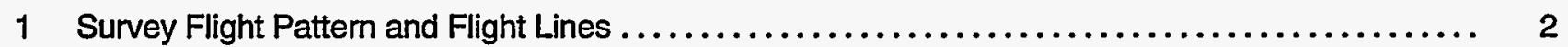

2 Total Terrestrial Plus Cosmic Isoradiațion Exposure Rate

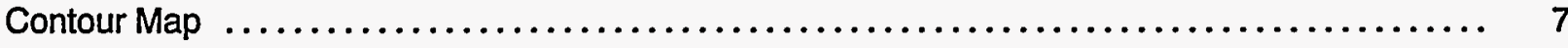

3 Man-Made Isoradiation Count Rate Contour Map $\ldots \ldots \ldots \ldots \ldots \ldots \ldots \ldots \ldots \ldots \ldots \ldots \ldots \ldots$

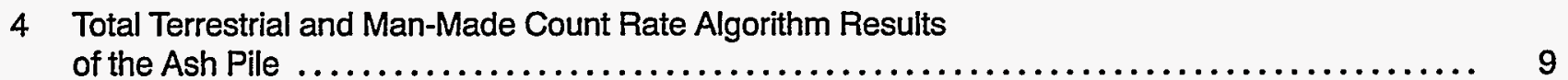

5 Total Terrestrial and Man-Made Count Rate Algorithm Results

6 Gamma Energy Spectrum of the Ash Pile Anomaly $\ldots \ldots \ldots \ldots \ldots \ldots \ldots \ldots \ldots \ldots \ldots \ldots \ldots$

7 Gamma Energy Spectrum of the Radiation Storage Facility $\ldots \ldots \ldots \ldots \ldots \ldots \ldots \ldots \ldots \ldots \ldots$

8 Total Terrestrial and Man-Made Count Rate Algorithm Results of the Northern Dayton Landfill $\ldots \ldots \ldots \ldots \ldots \ldots \ldots \ldots \ldots \ldots \ldots \ldots \ldots \ldots \ldots \ldots \ldots \ldots \ldots \ldots \ldots$ 
9 Total Terrestrial and Man-Made Count Rate Algorithm Results of a Steel Plant in the Northern Dayton Industrial Area $\ldots \ldots \ldots \ldots \ldots \ldots \ldots \ldots \ldots \ldots \ldots \ldots \ldots \ldots$

10 Gamma Energy Spectrum of the Northern Dayton Landfill $\ldots \ldots \ldots \ldots \ldots \ldots \ldots \ldots \ldots \ldots \ldots$

11 Gamma Energy Spectrum of a Stee! Plant in Northern Dayton $\ldots \ldots \ldots \ldots \ldots \ldots \ldots \ldots \ldots \ldots . \ldots \ldots$

12 Total Terrestrial and Man-Made Count Rate Algorithm Results



13 Gamma Energy Spectrum Collected near Crystal Lakes, Ohio $\ldots \ldots \ldots \ldots \ldots \ldots \ldots \ldots \ldots \ldots$

14 Gamma Energy Spectrum Typical of the Natural Background Radiation $\ldots \ldots \ldots \ldots \ldots \ldots \ldots \ldots$

\section{Tables}

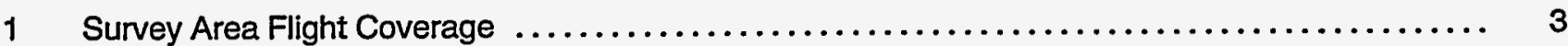

2 WPAFB Count Rates and Estimated Exposure Rate Levels $\ldots \ldots \ldots \ldots \ldots \ldots \ldots \ldots \ldots \ldots \ldots$

3 Summary of Terrestrial Exposure Rates for the WPAFB Area $\ldots \ldots \ldots \ldots \ldots \ldots \ldots \ldots \ldots \ldots \ldots$

4 Comparison of the Aerial and Ground-Based Measurements $\ldots \ldots \ldots \ldots \ldots \ldots \ldots \ldots \ldots \ldots \ldots$

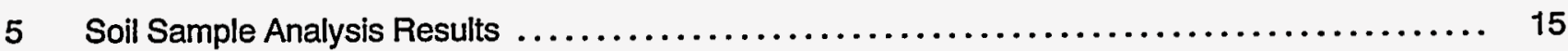

\section{Appendix}

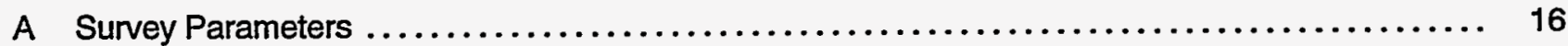

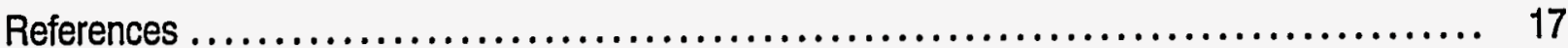




\subsection{INTRODUCTION}

From July $7-20,1994$, an aerial radiological survey was conducted at the request of the U.S. Department of Defense over Wright-Patterson Air Force Base (WPAFB) and nearby areas. Gamma radiation data were collected over $64 \mathrm{mi}^{2}\left(165.8 \mathrm{~km}^{2}\right)$ including: 1) a $60-\mathrm{mi}^{2}\left(155.4-\mathrm{km}^{2}\right)$ area centered on WPAFB, which includes portions of Dayton, Fairborn, Beavercreek, and Crystal Lakes, Ohio; and 2) a 4-mi² $\left(10.4-\mathrm{km}^{2}\right)$ area centered on a 95-acre property of WPAFB, located approximately $2 \mathrm{mi}(3.2 \mathrm{~km})$ east of WPAFB. The survey was conducted by the U.S. Department of Energy's (DOE) Remote Sensing Laboratory (RSL) using an aerial radiation measurement system. The RSL is operated by EG\&G Energy Measurements, Inc. (EG\&G/EM), a contractor for DOE.

The purpose of the survey was to acquire radiation data to determine the spatial distribution, identity, and quantity of the naturally-occurring and man-made gamma-emitting radionuclides in the two areas described above.

WPAFB conducted operations in the past that involved transporting, storing, and using nuclear materials, including the operation of a 91B research reactor. Presently, there are a number of areas on base where radioactive materials are licensed for use, including the medical center and the Air Force Institute of Technology.

\subsection{SITE DESCRIPTION AND HISTORY}

WPAFB is located in western Ohio, 9 miles $(14.5 \mathrm{~km})$ northeast of Dayton, and is adjacent to Fairborn on its western boundary (Figure 1). The Air Force base covers approximately 8,100 acres, which is divided into three areas designated as Areas $A, B$, and C. Radioactive materials were used and stored in Area $B$. Presently, Area B contains an entombed reactor, a concrete-filled facility where research involving the use of radioactive materials was conducted, and a radioactive materials storage area. The reactor last operated in the late 1960 s.

WPAFB is surrounded by the population centers of Dayton, Fairborn, Beavercreek, and Crystal Lakes, Ohio. The survey area includes a region which is farmed extensively. In the non-farming areas, the terrain is moderately to heavily vegetated, especially along the Miami River Valley.

\subsection{SURVEY OPERATIONS}

This survey was conducted to collect gamma radiation data over two areas comprising $64 \mathrm{mi}^{2}$ (165.8 $\mathrm{km}^{2}$ ) of WPAFB and the surrounding area using a thallium-activated sodium iodide, $\mathrm{Nal}(\mathrm{T} l)$, gamma ray detection system mounted on a MesserschmittBolkow-Blohm (MBB) BO-105 helicopter. The system was flown at an airspeed of 70 knots $(36 \mathrm{~m} / \mathrm{s})$, at an altitude of 150 feet (46 meters) above ground level (AGL), along parallel flight lines spaced 250 feet (76 meters) apart, totaling $1,352(2,176 \mathrm{~km})$ flight line miles. To minimize interference with Area $\mathrm{C}$ flight traffic at WPAFB, flight lines were oriented southwestnortheast (Figure 1). Position and aircraft steering information was provided by the Global Positioning System (GPS) input to the Radiation Environmental Data Acquisition and Recorder, Model IV (REDAR IV). Systems and procedures are discussed in detail in a separate publication. ${ }^{1}$

The main area of $60 \mathrm{mi}^{2}\left(155 \mathrm{~km}^{2}\right)$ centered on WPAFB was 5 miles $(8.0 \mathrm{~km})$ wide by 12 miles $(19.3$ $\mathrm{km}$ ) long, extending from the northeast corner of Dayton, Ohio, to approximately 3 miles $(4.8 \mathrm{~km})$ northeast of the property perimeter of WPAFB. The width of the pattern extended westward 5 miles $(8.0 \mathrm{~km})$ from the western edge of the town of Fairborn, Ohio.

A second area covered was $4 \mathrm{mi}^{2}\left(10.4 \mathrm{~km}^{2}\right)$ in size, centered on a .15-mi $\left(96\right.$-acre or $\left.0.39-\mathrm{km}^{2}\right)$ WPAFB property located approximately $2 \mathrm{mi}(3.2 \mathrm{~km})$ east of the base, Figure 1. See Table 1 for details of the flight coverage.

\subsection{DATA ANALYSIS}

The data collected over the areas previously described were processed during field operations to map the radiation profile of the WPAFB area. The objectives of the processing were: 1) to establish the spatial distribution of the gamma radioactivity, 2) to identify the radionuclides contributing to the gamma exposure, and 3 ) to estimate the quantity of radionuclides present relative to the exposure rate. To achieve the desired results, isoradiation count rate contours of natural and man-made sources were generated and superimposed on high altitude aerial photographs. Gamma ray spectra were examined for all anomalies that were significantly elevated (by a factor of 2 or more) above typical terrestrial values. Isoradiation count rate contour maps were generated for those sources found to be significantly distributed in the surveyed areas. 


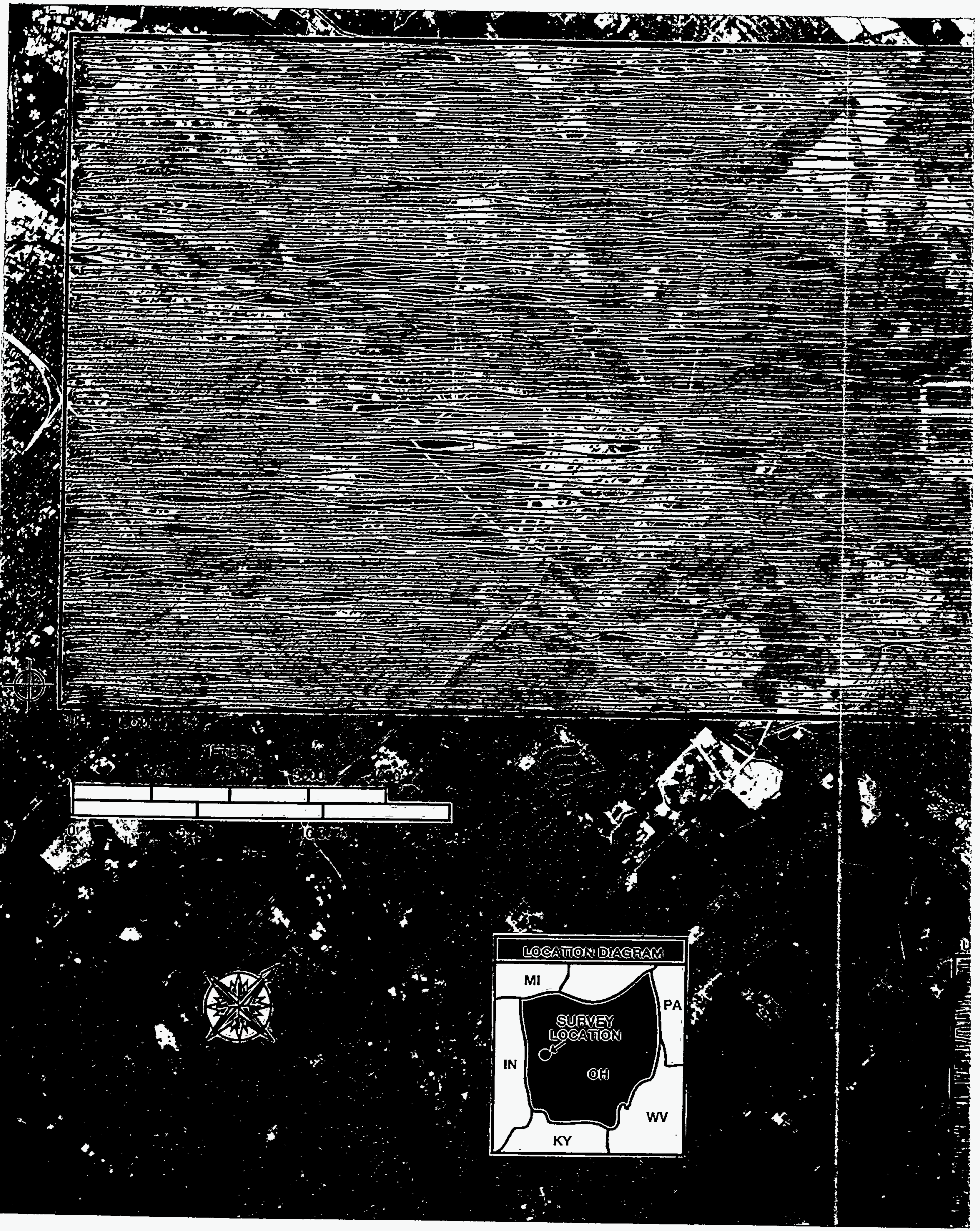




\begin{tabular}{|c|c|c|c|c|c|c|}
\hline \multirow{2}{*}{} & \multicolumn{2}{|c|}{ Table 1. Survey Area Flight Coverage } \\
\hline & \multicolumn{2}{|c|}{ Area } & \multicolumn{2}{c|}{ Flight Lines } & \multicolumn{2}{c|}{$\begin{array}{c}\text { Flight Line } \\
\text { Distance }\end{array}$} \\
\cline { 2 - 7 } Location & $\mathrm{mi}^{2}$ & $\mathbf{k m}^{2}$ & No. & $\begin{array}{c}\text { Length } \\
(\mathbf{m i})\end{array}$ & $\mathrm{mi}$ & $\mathbf{~ k m}$ \\
\hline Area 1 & 60 & 155.4 & 106 & 12 & 1,272 & 2,047 \\
Area 2 & 4 & 10.4 & 40 & 2 & 80 & 129 \\
Total & 64 & $\mathbf{1 6 5 . 8}$ & $\mathbf{1 4 6}$ & & $\mathbf{1 , 3 5 2}$ & $\mathbf{2 , 1 7 6}$ \\
\hline
\end{tabular}

The primary data processing involves applying algorithms that extract net photopeak count rates of specific sources from multichannel spectral data collected and recorded each second of flight over the areas of interest. The count rate data are combined with position information to produce the isoradiation contour maps.

\subsection{Search Algorithms}

Algorithms were generated to extract the count rate due to gamma rays emitted by the following sources:

A. Total Terrestrial and Cosmic Radionuclides Gross Count

$$
C R_{G C}=\sum_{E=38}^{3026} C R_{E}-N T B
$$

where

$C R_{G C}=$ total terrestrial count rate; i.e., count rate produced by gamma rays with energies in the range $E \gamma \geq 38 \mathrm{keV}$ to $E \gamma \leq 3,026 \mathrm{keV}$

$C R_{E}=$ count rate produced by a gamma ray with energy $E$

$N T B=$ non-terrestrial background; i.e., count rates produced by airborne radon, gamma emitters of the detector platform, and gamma rays of cosmic origin

B. Total Terrestrial Man-Made Radionuclides MMGC

$$
C R_{M M G C}=\sum_{E=38}^{1394} C R_{E}-K \cdot \sum_{E=1394}^{3026} C R_{E}
$$

$C R_{M M G C}$ is the count rate from man-made terrestrial gamma emitters; i.e., count rate produced by gamma rays in the range $E \gamma \geq 38$ $\mathrm{keV}$ to $\mathrm{E}_{\gamma} \leq 1,394 \mathrm{keV}$. Many frequently detected man-made gamma emitters fall in this range. This algorithm is also sensitive to elevated count rate levels of certain naturally-occurring gamma emitters.

The algorithm results are illustrated in Section 5 and their derivations are discussed in more detail in a separate publication. ${ }^{2}$

In the man-made algorithm, $K$ is the ratio of the source photopeak window to the background photopeak window computed from data collected where no manmade sources are present.

$$
K_{i}=\frac{\sum_{E_{1}}^{E_{2}} C R_{E}(\text { Source })}{\sum_{E_{3}}^{E_{4}} C R_{E}(\text { Background })}
$$

$K$ is derived from the data of each flight to minimize the effects of airborne radon-222 (222Rn) and minor system characterization differences between flights.

The count rate of the total terrestrial activity was converted to exposure rate at one meter AGL by applying a conversion factor of 1,071 counts per second (cps) per microroentgen per hour $(\mu \mathrm{R} / \mathrm{h})$. This conversion 
factor was derived from count rate and exposure rate data collected over a test range in Calvert County, Maryland. The gross count rate conversion function is written as

$$
E R=\frac{C R c p s}{1071 \frac{c p s}{\mu R / h}}
$$

where

$$
\begin{gathered}
C R=\text { count rate from } \mathrm{Nal}(\mathrm{T} l) \text { detectors in } \mathrm{cps} \\
\text { measured at the survey altitude }
\end{gathered}
$$

It should be noted that in areas of atypical mixes of gamma-emitting radionuclides, the converted values will incorrectly estimate the actual exposure rate. Table 2 lists the count rates measured at the survey altitude and their estimated equivalent exposure rate levels at one meter AGL. An estimated cosmic ray contribution of $4 \mu \mathrm{R} / \mathrm{h}$ was added to the reported exposure rate levels.

The extracted count, using the man-made algorithm, was used to generate isoradiation count rate contour maps that aided in locating and identifying the relative intensity and spatial distribution of man-made gamma-emitting radionuclides that may be present in the surveyed areas.

\subsection{Data Uncertainty}

The uncertainty, $\sigma_{C R}$, in the count rate generated by the algorithms previously discussed is described in other EG\&G/EM survey reports. ${ }^{2}$ The general equation for $\sigma_{C R}$ relative to the algorithms described previously is:

$$
\sigma_{C R}=\sqrt{K_{1}^{2} \cdot \sum_{E_{3}}^{E_{4}} C R_{E}+K_{2}^{2} \cdot \sum_{E_{3}}^{E_{4}} C R_{E}+\ldots+K_{i}^{2} \cdot \sum_{E_{n-1}}^{E_{n}} C R_{E}}
$$

Some multiple of the uncertainty, $n \sigma_{C R}$, is chosen to optimally separate source activity from statistical fluctuations in counting the source of interest at a particular confidence interval. Statistical excursions of various algorithm results were evaluated to determine their origin. Generally, several contour maps are generated for a specific radionuclide with selected values of $n$ to ensure that the low-level trends in man-made source activity are not suppressed. Also, it is often useful to choose the levels to show variations in the natural environment (vegetation, waterways, land use, etc.) to verify the dynamic range of sensitivity of the detector system.

The uncertainty in the estimated exposure rate values is about $0.5 \mu \mathrm{R} / \mathrm{h}$. Derivation of this value is discussed in detail in a separate publication. ${ }^{1}$ The results of the man-made algorithm were normally distributed about

\begin{tabular}{|c|c|c|}
\hline \multicolumn{2}{|c|}{ Table 2. } & $\begin{array}{c}\text { WPAFB Count Rates and Estimated } \\
\text { Exposure Rate Levels }\end{array}$ \\
\hline $\begin{array}{c}\text { Letter } \\
\text { Label }\end{array}$ & $\begin{array}{c}\text { Total Count Rate } \\
\text { (cps) }^{\mathbf{a}}\end{array}$ & $\begin{array}{c}\text { Exposure Rate } \\
(\mu \mathrm{R} / \mathrm{h})^{\mathbf{b}}\end{array}$ \\
\hline A & $<1,071$ & $<5$ \\
B & $1,071-3,213$ & $5-7$ \\
C & $3,213-5,355$ & $7-9$ \\
D & $5,355-9,639$ & $9-13$ \\
E & $9,639-16,065$ & $13-19$ \\
F & $16,065-32,130$ & $19-34$ \\
\hline
\end{tabular}

a The airborne contributions have been removed from the count rates.

b These exposure rate values are estimated from Column 2 and include an additional estimated cosmic contribution of $4 \mu \mathrm{R} / \mathrm{h}$. 
area surveyed. Exposure rates were measured with a pressurized ionization chamber for comparison to the values inferred from the aerial data. Soil samples were taken at all six ground sampling points in order to determine the radionuclide concentrations typical of the natural background in the area. In addition, estimates of the exposure rates due to these radionuclide concentrations were made from the soil sample analyses. The soil samples were analyzed and the results tabulated for this report by scientists at the former EG\&G/EM Santa Barbara Laboratory. Systems and procedures for soil sample data collection and analysis are outlined in separate publications.3,4

\subsection{RESULTS}

\subsection{Data Summary}

The results of the survey are presented as: 1) isoradjation contour maps of total terrestrial and man-made gamma ray count rates, and 2) gamma energy spectra of regions depicted on the man-made count rate contours. The total terrestrial count rates are converted to equivalent gamma ray exposure rates, in $\mu R / h$, as described in Section 4 and illustrated in Figure 2. The contour map illustrated in Figure 3 represents the count rate contours generated from the algorithm that is used to extract man-made gamma radiation as defined in Section 4.

\subsection{Detected Man-Made Activity}

Five localized sources of gamma radiation, (numbered from 1-5 on the man-made contour map, Figure 3) validated by the man-made algorithm and atypical of radionuclides found in the area, were detected in the larger of the two areas surveyed. Two of the five sources were detected on WPAFB property: an ash pile near the Area $C$ flight line (location 1) and a radiation storage facility in Area B (location 2). Figures 4 and 5 show the way in which these man-made count rate anomalies were detected along their particular survey flight paths.

Figure 6 illustrates the gamma energy spectrum of the Area $C$ ash pile. The gamma energy spectrum with typical natural background radiation removed depicts low energy, scattered gamma emitters with no dominant photopeaks.
Figure 7 shows the gamma energy spectrum taken over the radiation storage facility. The spectrum depicts the presence of a complex mix of man-made gamma emitters. The dominant photopeak is that of the $514-\mathrm{keV}$ gamma ray of krypton-85 $\left({ }^{85} \mathrm{Kr}\right)$. This material was present in the storage facility at the time of the survey.

Three areas of atypical gamma activity were detected outside the WPAFB property. Two sources were detected in an industrial area of northern Dayton, Ohio. Spectral analysis revealed the presence of cesium-137 $\left({ }^{137} \mathrm{Cs}\right)$ in excess of worldwide fallout levels at a northern Dayton landfill. Apparently, an intermittently used source was detected over a steel plant in the same industrial area. Both aerial and ground-based measurements confirmed the intermittent use of a gamma radiation source at the steel plant, most likely from $\mathrm{X}$-ray radiography. The total terrestrial and man-made algorithm results (count rate) of the two northern Dayton sources are shown in Figures 8 and 9.

The photopeak of ${ }^{137} \mathrm{Cs}$ is depicted in the gamma energy spectrum taken over the landfill anomaly, Figure 10. A mix of low energy gamma rays is depicted in the gamma energy spectrum taken over the steel plant anomaly, Figure 11.

A localized source atypical of the natural radionuclide mix in the area was detected at Crystal Lakes, Ohio, near the survey's north boundary. Figure 12 depicts the total terrestrial and man-made algorithm results over this anomaly. An 192Ir source is known to exist in this area and is used in a number of industrial activities. The gamma ray spectrum collected in this area exhibits only a well-defined ${ }^{137} \mathrm{Cs}$ peak and some excess low energy gamma rays (see Figure 13). The ${ }_{192}$ Ir source was shielded from the detectors or not present at the time of the flight in this area.

Only naturally-occurring gamma-emitting radionuclides (uranium-238 and progeny, thorium-232 and progeny, and potassium-40) typical of the entire area were detected on the 95-acre WPAFB site, Figure 14.

\subsection{CONCLUSION}

An aerial radiological survey was conducted over areas of Wright-Patterson Air Force Base and the surrounding area during the period July 7 through 20 , 1994. Five localized gamma radiation sources were found. Table 3 summarizes the distribution of exposure rates at WPAFB and its surrounding area. 


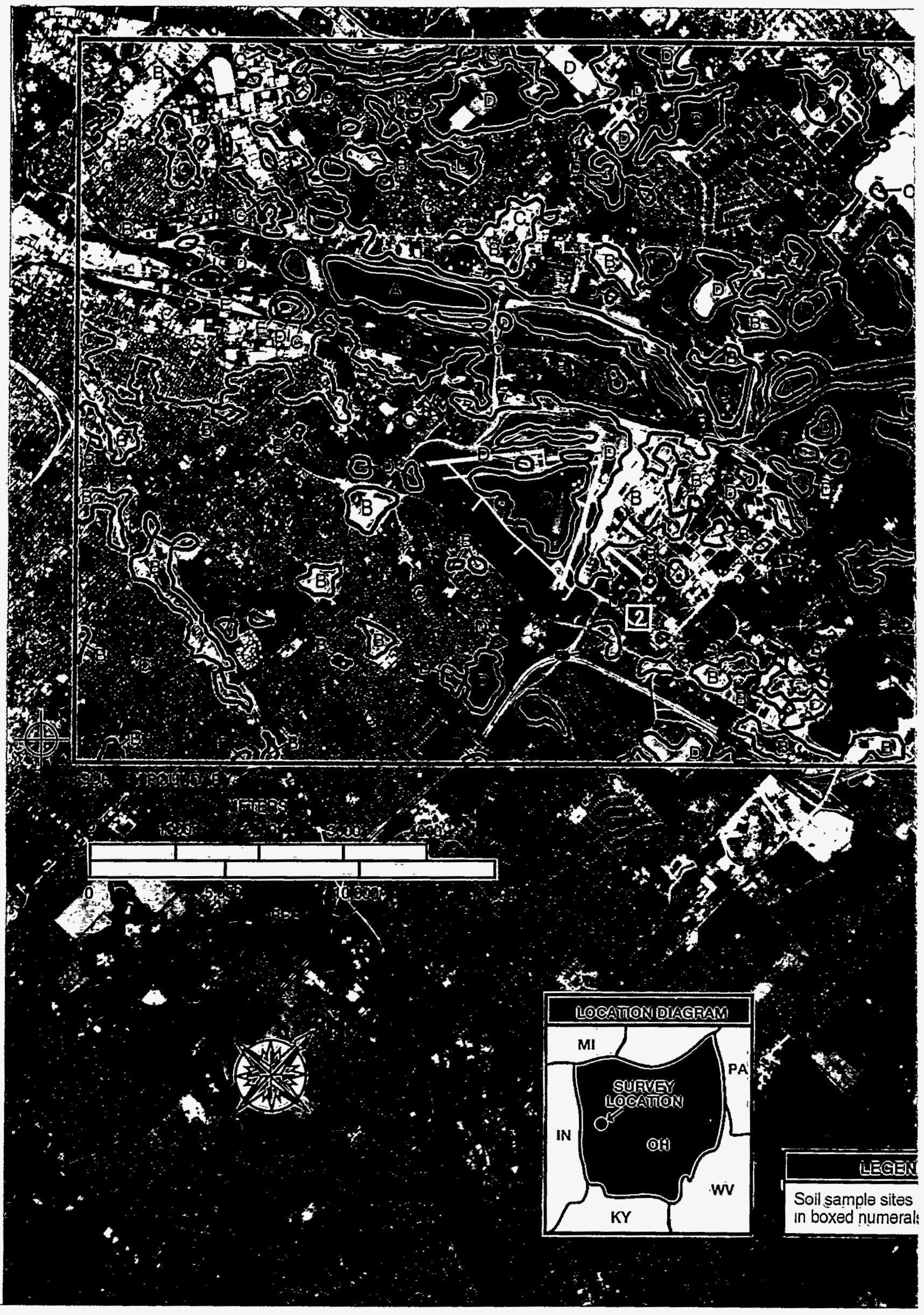

FIGURE 2. TOTAL TERRESTRIAL PLUS COSMIC ISORADIATION EXPOSURE RATE CONTOUR MAP 


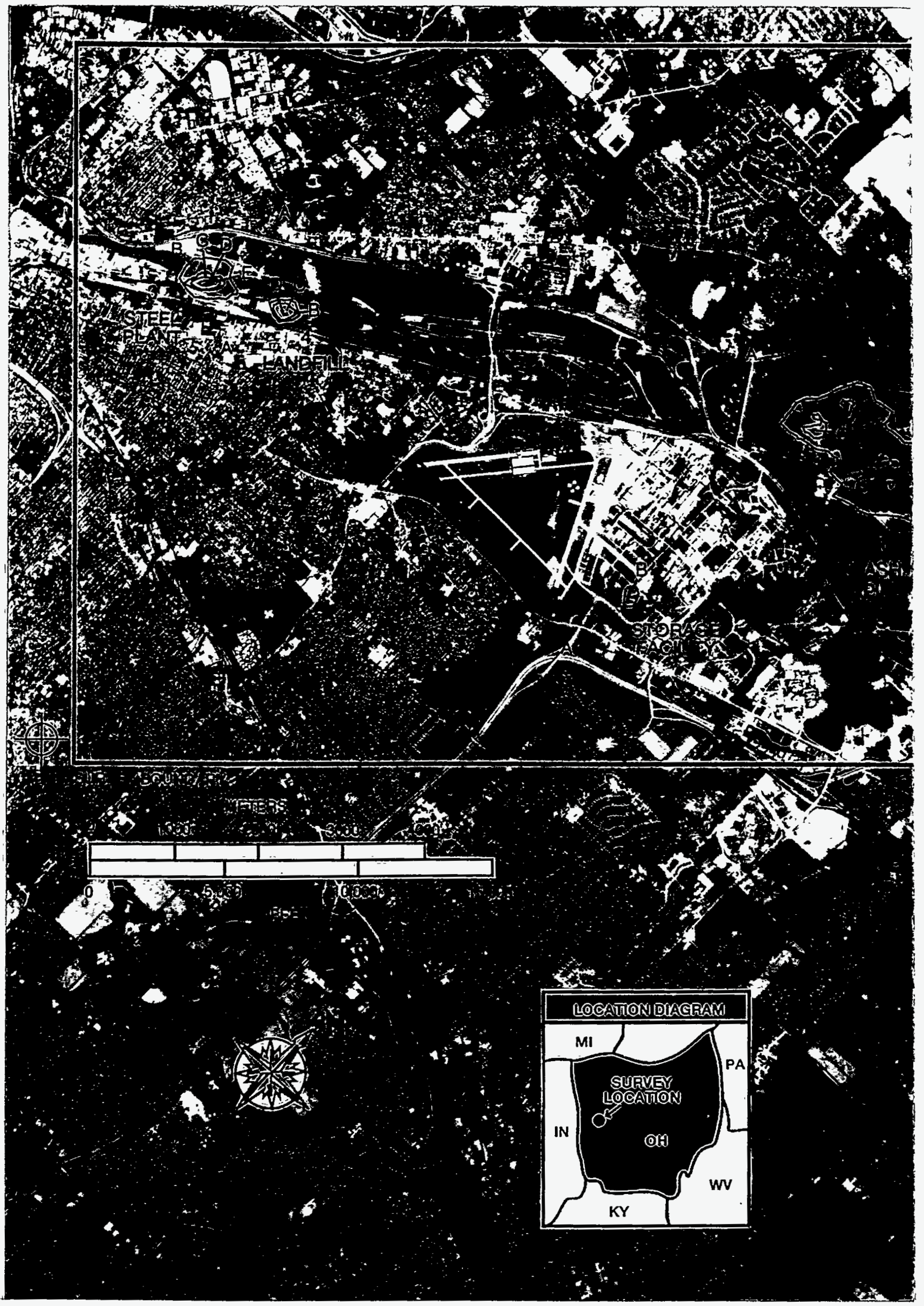

FIGURE 3. MAN-MADE ISORADIATION COUNT RATE CONTOUR MAP 


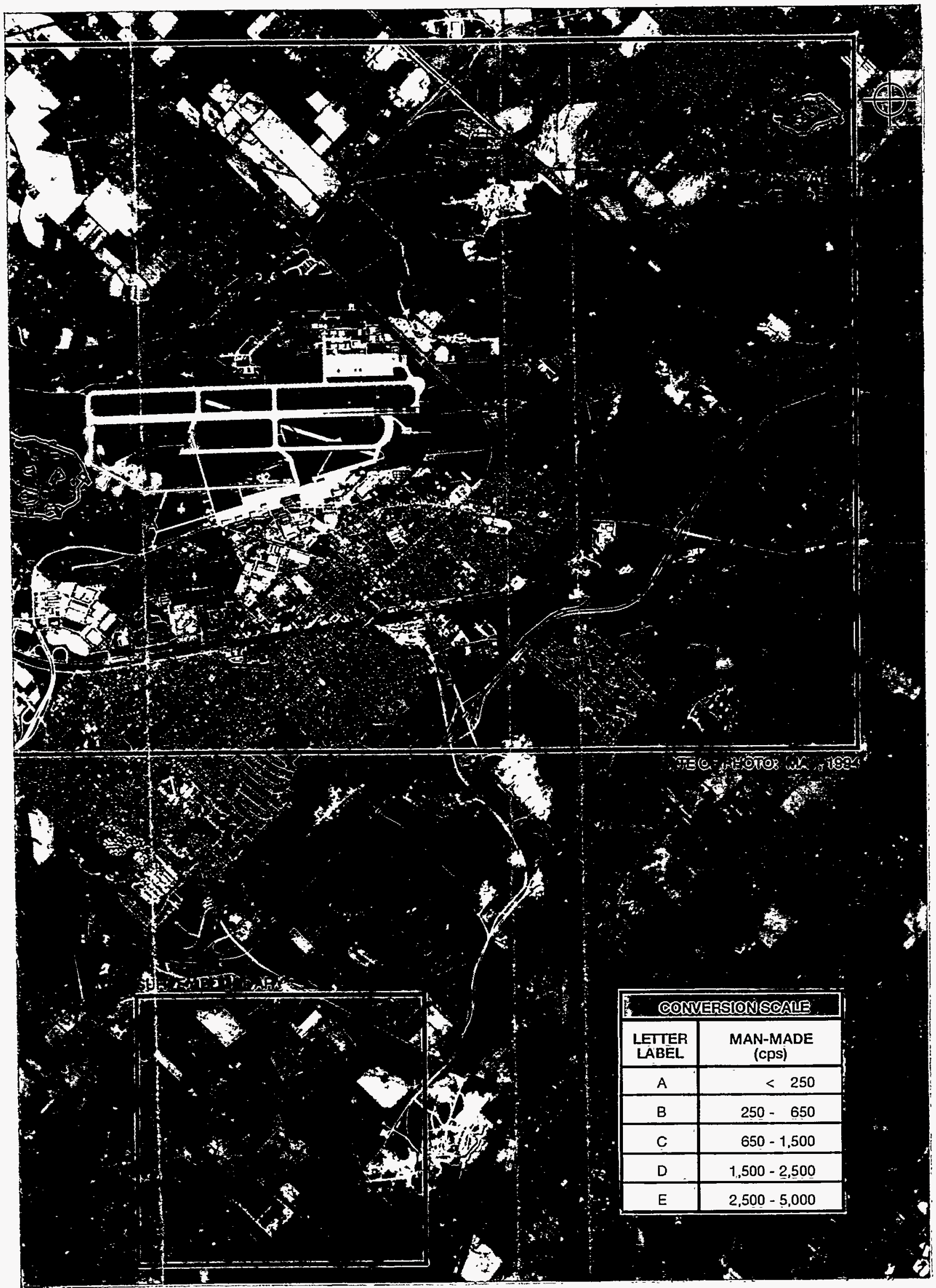






FIGURE 4. TOTAL TERRESTRIAL AND MAN-MADE COUNT RATE ALGORITHM RESULTS OF THE ASH PILE

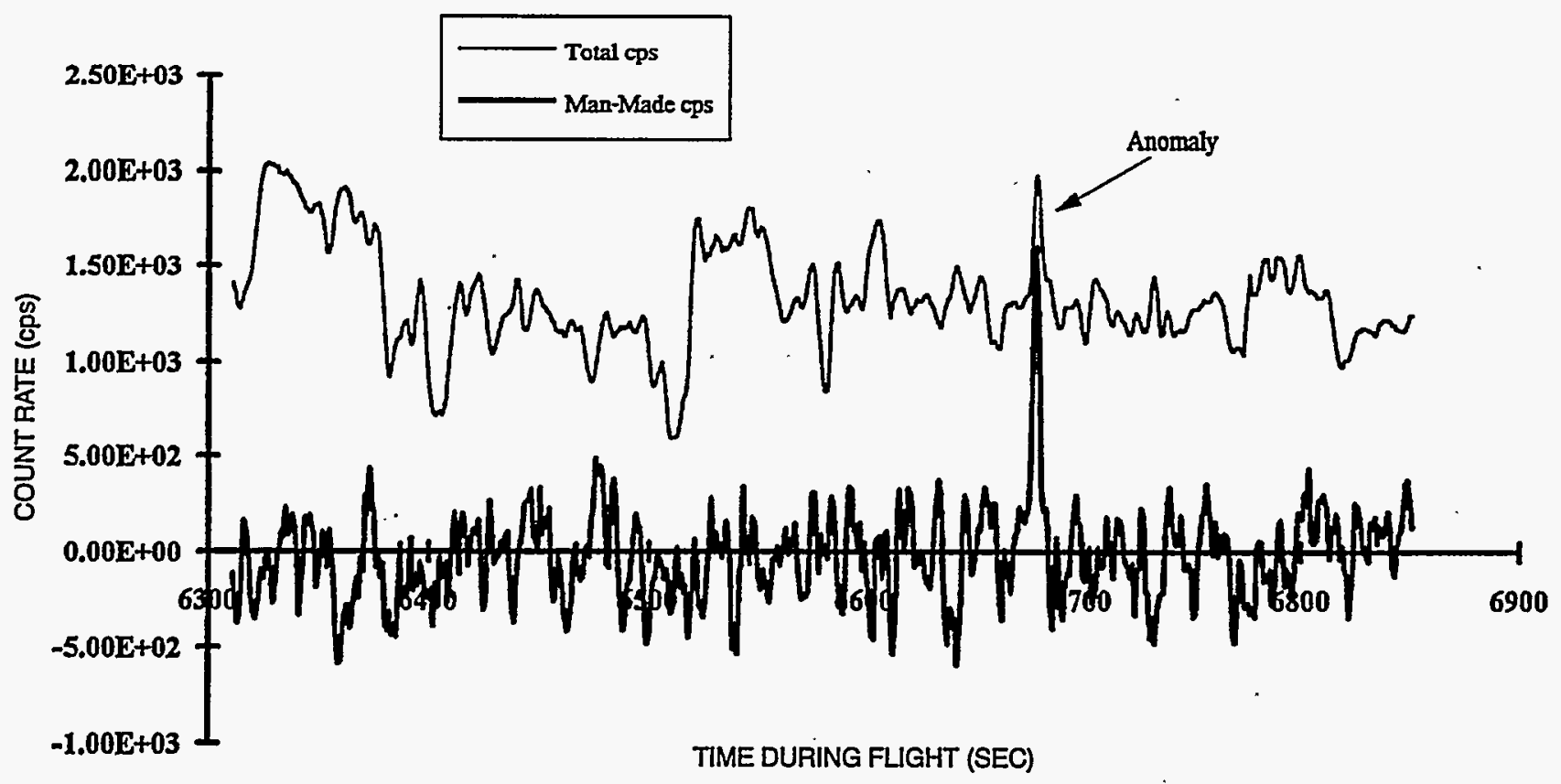

FIGURE 5. TOTÁL TERRESTRIAL AND MAN-MADE COUNT RATE ALGORITHM RESULTS OF THE RADIATION STORAGE FACILITY

9 


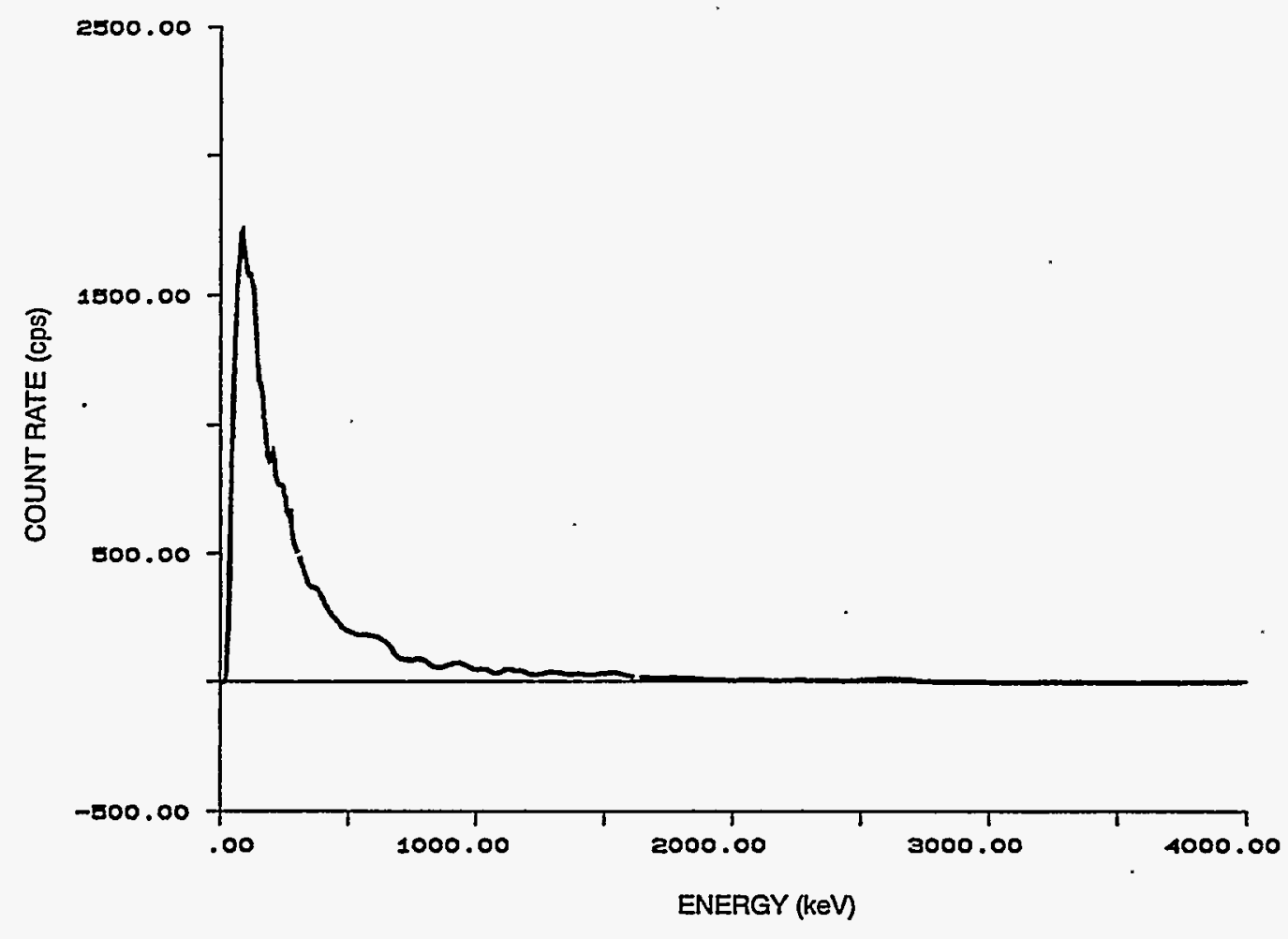

. FIGURE 6. GAMMA ENERGY SPECTRUM OF THE ASH PILE ANOMALLY

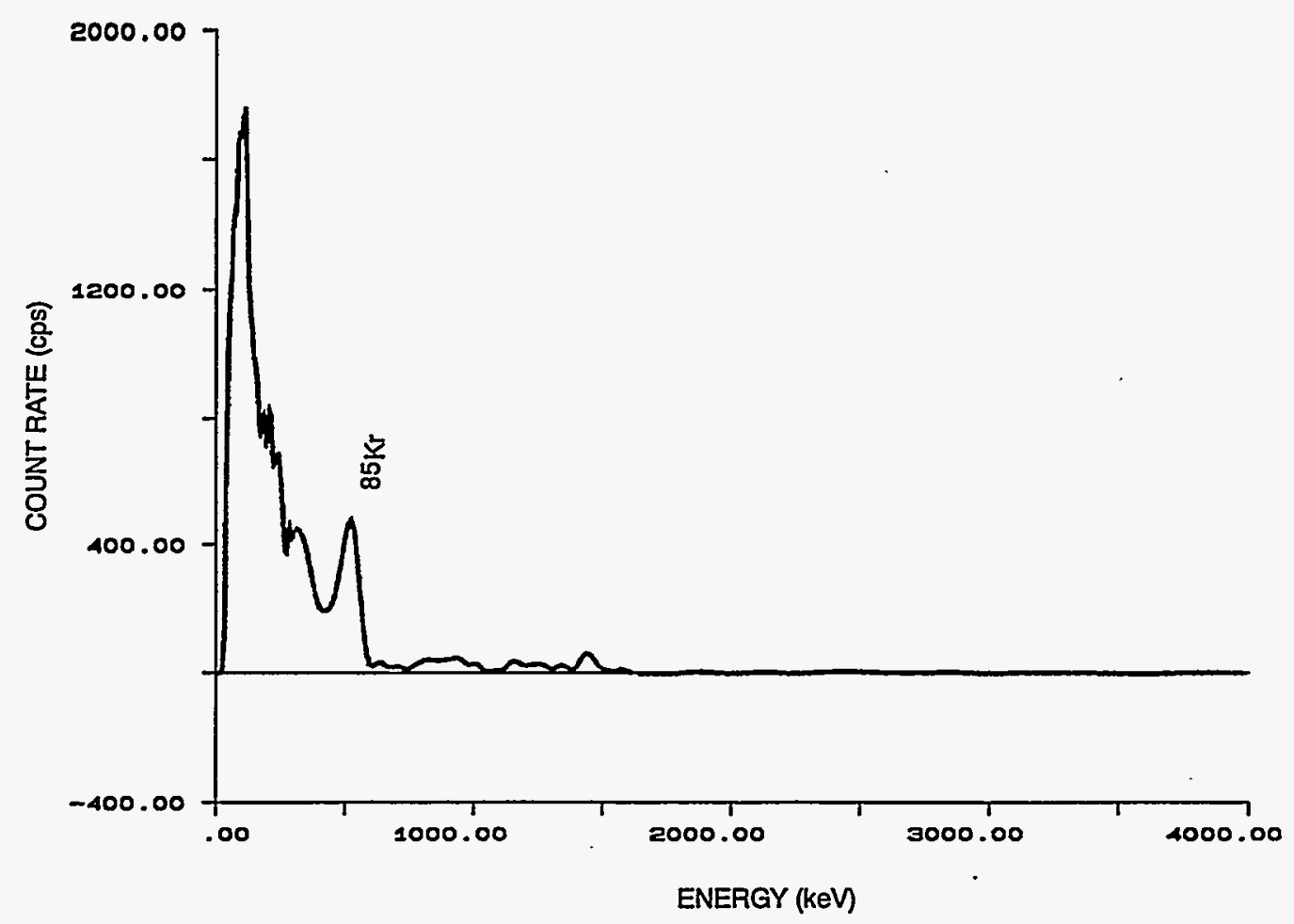

FIGURE 7. GAMMA ENERGY SPECTRUM OF THE RADIATION STORAGE FACILITY 




FIGURE 8. TOTAL TERRESTRIAL AND MAN-MADE COUNT RATE ALGORITHM RESULTS OF THE NORTHERN DAYTON LANDFILL

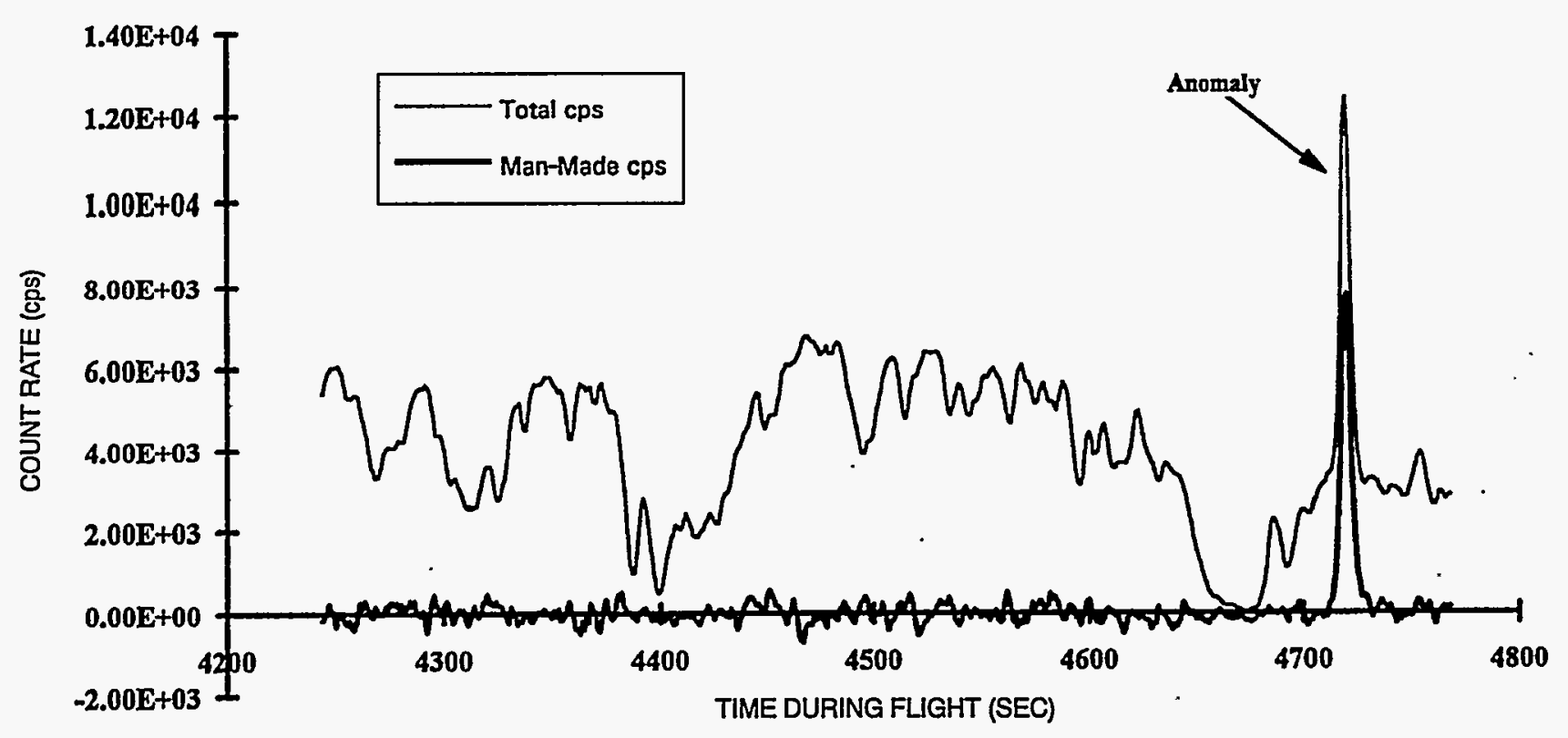

FIGURE 9. TOTAL TERRESTRIAL AND MAN-MADE COUNT RATE ALGORITHM RESULTS OF A STEEL PLANT IN THE NORTHERN DAYTON INDUSTRIAL AREA 


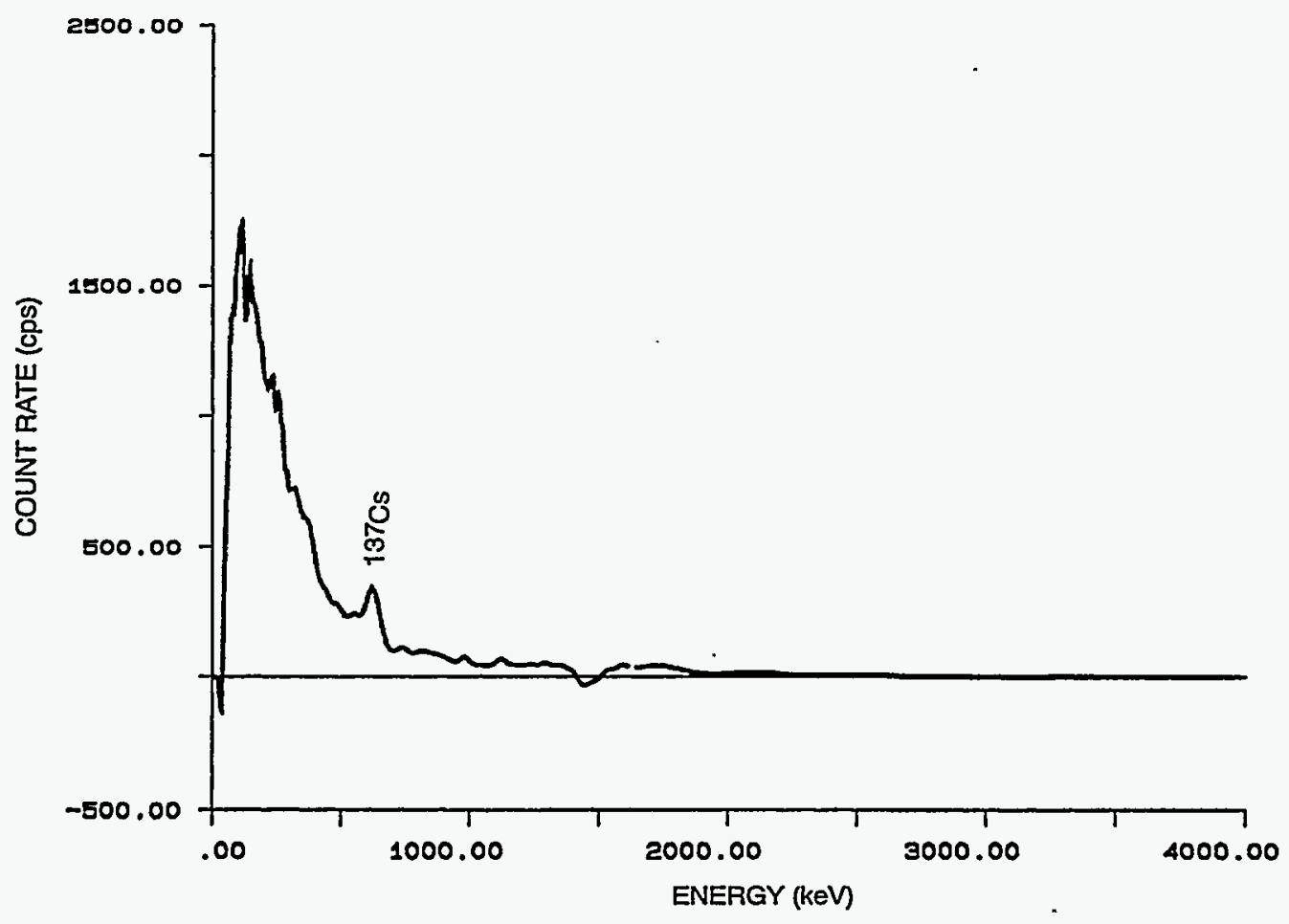

FIGURE 10. GAMMA ENERGY SPECTRUM OF THE NORTHERN DAYTON LANDFILL

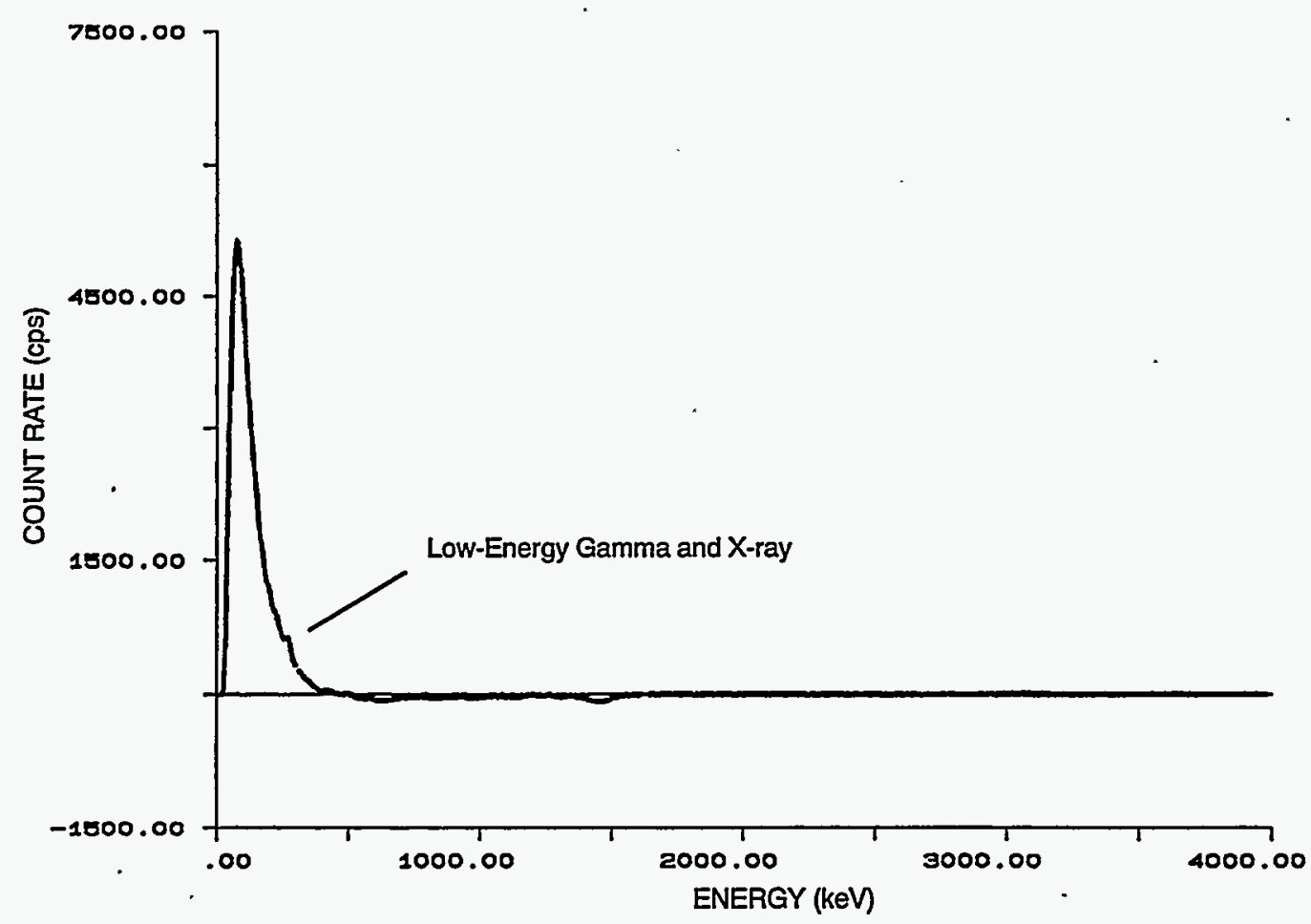

FIGURE 11. GAMMA ENERGY SPECTRUM OF A STEEL PLANT IN NORTHERN DAYTON 


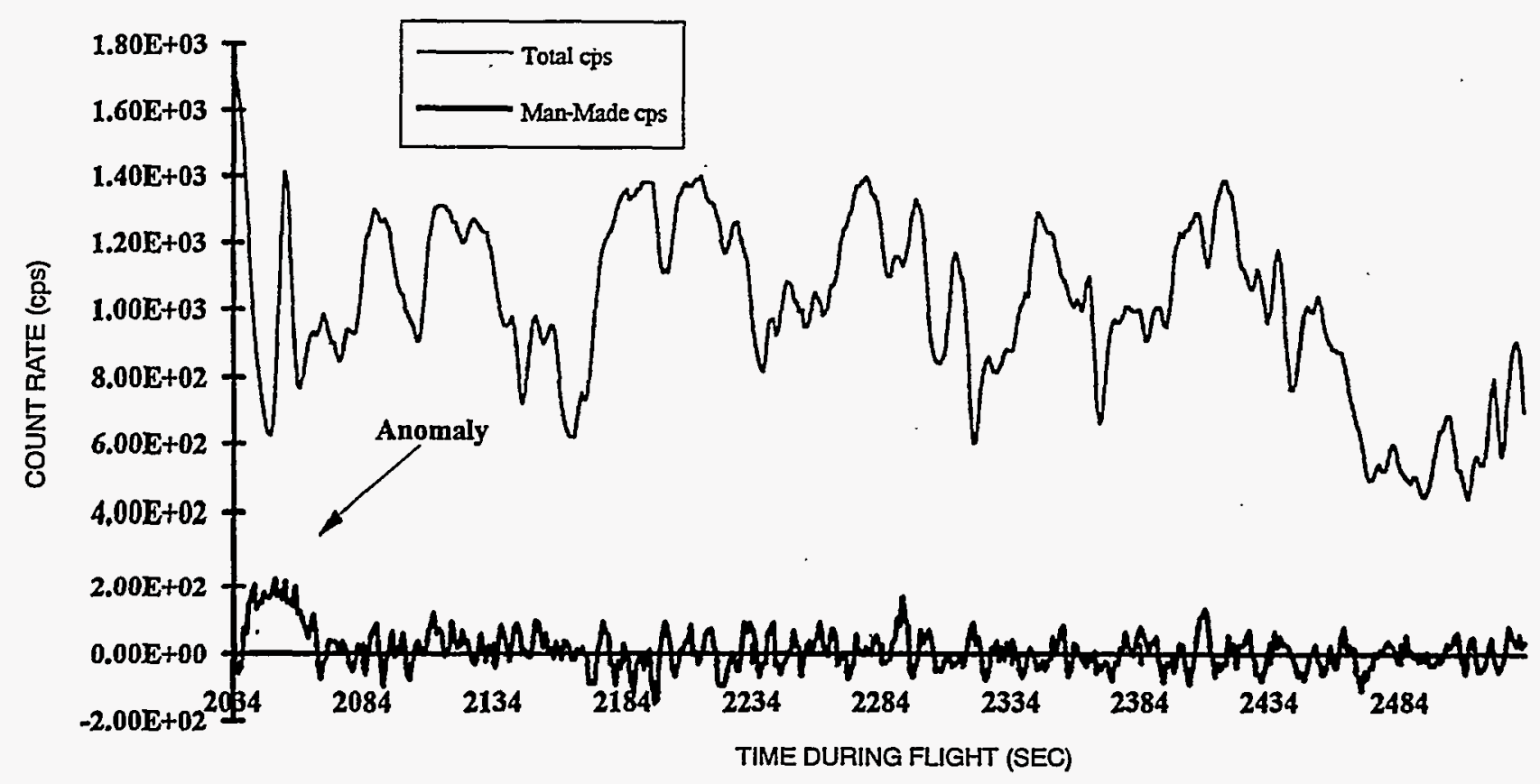

FIGURE 12. TOTAL TERRESTRIAL AND MAN-MADE COUNT RATE ALGORITHM RESULTS OF CRYSTAL LAKES, OHIO

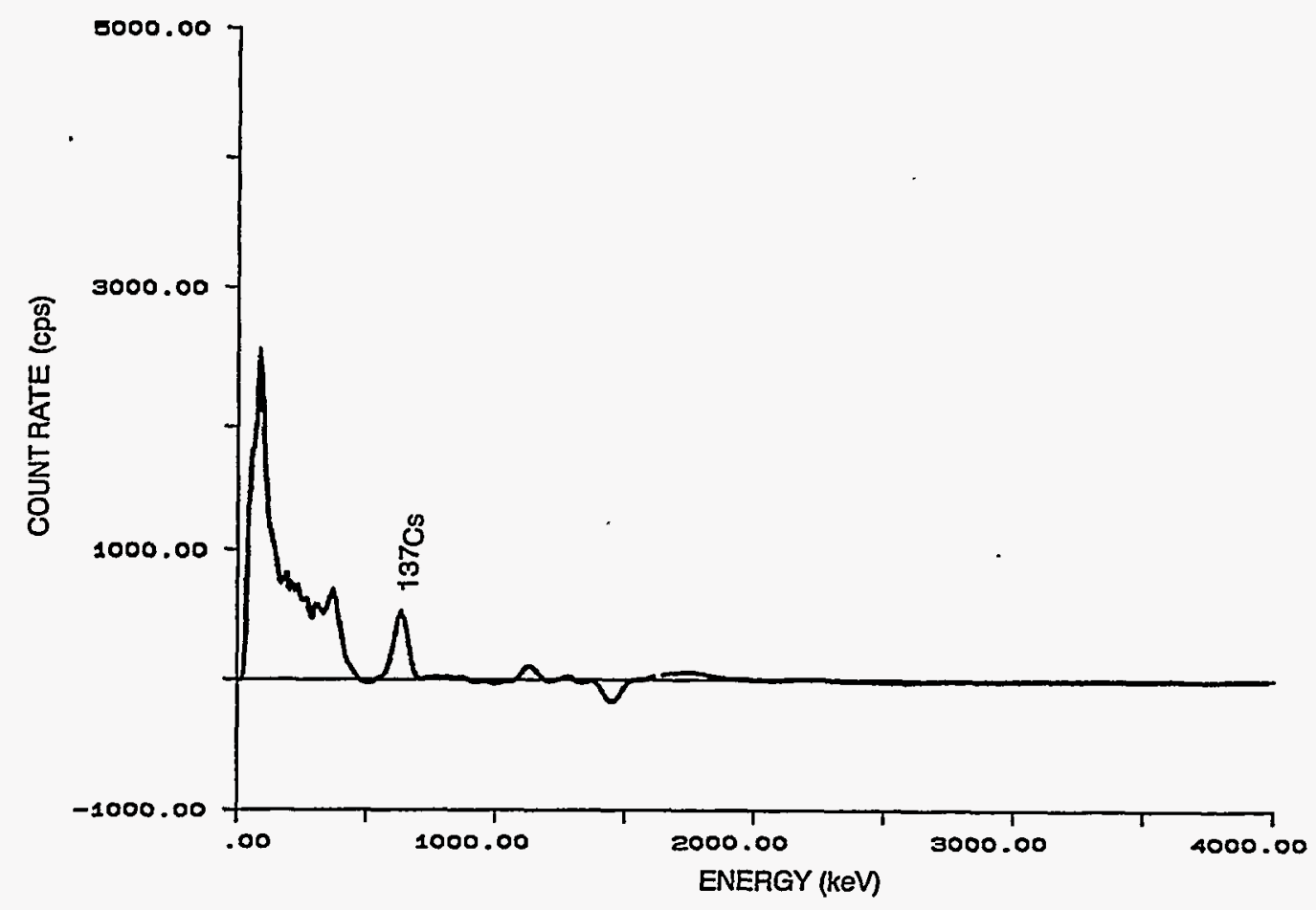

FIGURE 13. GAMMA ENERGY SPECTRUM COLLECTED NEAR CRYSTAL LAKES, OHIO 




FIGURE 14. GAMMA ENERGY SPECTRUM TYPICAL OF THE NATURAL BACKGROUND RADIATION

\begin{tabular}{|c|c|c|c|}
\hline Terrain Description (type) & $\begin{array}{c}\text { Terrestrial and } \\
\text { Cosmic } \\
\text { Exposure Rates } \\
(\mu R / h)\end{array}$ & Terrestrial Source & Origin \\
\hline Farm Land & $9-13$ & ${ }^{40} \mathrm{~K},{ }^{238} \mathrm{U},{ }^{232} \mathrm{Th}$ & Natural \\
\hline River/River Basin & $5-7$ & ${ }^{40} \mathrm{~K},{ }^{238} \mathrm{U},{ }^{232} \mathrm{Th}$ & Natural \\
\hline Heavy Vegetation & $5-7$ & ${ }^{40} \mathrm{~K},{ }^{238} \mathrm{U}, 232 \mathrm{Th}$ & Natural \\
\hline Housing Areas & $7-9$ & $40 \mathrm{~K}, 238 \mathrm{U},{ }^{232} \mathrm{Th}$ & Natural \\
\hline Concrete/Asphalt & $7-9$ & $40 \mathrm{~K}, 238 \mathrm{U},{ }^{232} \mathrm{Th}$ & Natural \\
\hline *Ash Pile (1) & $10+$ & Enhanced Natural & Enhanced Natural \\
\hline * Radiation Storage Facility (2) & $9+$ & $85 \mathrm{Kr}$ & Man-Made \\
\hline *Steel Plant (3) & $16+$ & X-Ray & Radiography \\
\hline *Landfill (4) & $14+$ & ${ }^{137} \mathrm{Cs},{ }^{232} \mathrm{Th}$ & Refractory Bricks \\
\hline $\begin{array}{l}\text { *Anomaly northwest of } \\
\text { Crystal Lakes, Ohio (5) }\end{array}$ & $14 t$ & ${ }^{137} \mathrm{Cs},{ }^{192} \mathrm{Ir}$ & Unknown \\
\hline
\end{tabular}


The typical exposure rate levels, including those occurring naturally and those found in the five localized areas, were 9 to $13 \mu \mathrm{R} / \mathrm{h}$ at one meter above ground level in uncovered ground area forms. Areas covered with road tops, concrete, housing, and heavy vegetation had exposure rate levels ranging from 5 to $7 \mu \mathrm{R} / \mathrm{h}$. The detected exposure rates are well within the range ( 1 to $20 \mu \mathrm{R} / \mathrm{h}$ ) found throughout the contiguous United States, Hawaii, and Alaska. ${ }^{5}$

Table 4 compares the exposure rate results obtained from the aerial data with the results obtained from ground-based measurements taken during the survey. The fact that the aerial system measures an area several thousand times larger than a typical ion chamber measurement taken at 1 meter above ground and several million times larger than a typical soil sample should be considered when comparing these different types of measurements. The ground measurement results are listed in Table 5. The values given in Table 4 show that good agreement was obtained between the different measurement techniques for the WPAFB survey.

Table 4. Comparison of the Aerial and Ground-Based Measurements ${ }^{\text {a }}$

\begin{tabular}{|c|c|c|c|}
\hline \multirow{2}{*}{ Site } & \multicolumn{3}{|c|}{$\begin{array}{c}\text { Exposure Rate } \\
(\mu \mathrm{R} / \mathrm{h} \text { at 1 Meter AGL })\end{array}$} \\
\cline { 2 - 4 } & Soil Analysis $^{\mathrm{b}}$ & lon Chamber $^{\mathrm{c}}$ & Aerial Data $^{\mathrm{d}}$ \\
\hline 1 & $10.7 \pm 1.0$ & $10.0 \pm 0.5$ & $9.6 \pm .1$ \\
\hline 2 & $8.6 \pm 0.9$ & $8.9 \pm 0.5$ & $7.9 \pm .1$ \\
\hline 3 & $7.7 \pm 1.7$ & $8.0 \pm 05$ & $8.1 \pm .3$ \\
\hline 4 & $7.4 \pm 0.6$ & $8.1 \pm 0.5$ & $7.3 \pm .2$ \\
\hline 5 & $11.1 \pm 0.9$ & $9.6 \pm 0.5$ & $9.9 \pm .2$ \\
\hline 6 & $10.5 \pm 0.9$ & $9.3 \pm 0.5$ & $9.2 \pm .3$ \\
\hline
\end{tabular}

a All numbers have the cosmic ray contribution included.

b Exposure rate value includes a cosmic ray contribution of $4 \mu \mathrm{R} / \mathrm{h}$ and a moisture correction factor of the form $1 /(1+m)$.

c Reuter-Stokes Pressurized lon Chamber Model \#RSS-112, Serial No. \# G-003.

dUncertainties in aerial data are statistical counting uncertainties only.

\begin{tabular}{|c|c|c|c|c|c|}
\hline \multicolumn{7}{|c|}{ Table 5. Soil Sample Analysis Results } \\
\hline Site & $\begin{array}{c}\text { Soil Moisture } \\
(\%)\end{array}$ & $\begin{array}{c}{ }^{226} \mathrm{Ra} \\
(\mathrm{pCi} / \mathrm{g})\end{array}$ & $\begin{array}{c}232 \mathrm{Th} \\
(\mathrm{pCi} / \mathrm{g})\end{array}$ & $\begin{array}{c}{ }^{137} \mathrm{Cs} \\
(\mathrm{pCi} / \mathrm{g})\end{array}$ & $\begin{array}{c}40 \mathrm{~K} \\
(\mathrm{pCi} / \mathrm{g})\end{array}$ \\
\hline 1 & $4.0 \pm 1.0$ & $0.9 \pm 0.1$ & $0.95 \pm .19$ & $0.43 \pm .19$ & $16.0 \pm 0.9$ \\
\hline 2 & $2.3 \pm 1.0$ & $0.6 \pm 0.1$ & $0.6 \pm 0.1$ & $0.03 \pm 0.02$ & $12.6 \pm 1.5$ \\
\hline 3 & $1.5 \pm 0.2$ & $0.6 \pm 0.2$ & $0.5 \pm 0.2$ & $0.12 \pm .06$ & $9.0 \pm 3.0$ \\
\hline 4 & $8.1 \pm 0.7$ & $0.7 \pm 0.1$ & $0.4 \pm 0.07$ & $0.29 \pm .09$ & $8.2 \pm 1.1$ \\
\hline 5 & $7.0 \pm 1.0$ & $1.1 \pm 0.1$ & $1.0 \pm 0.06$ & $0.27 \pm .04$ & $16.4 \pm 0.8$ \\
\hline 6 & $11.0 \pm 3.0$ & $1.1 \pm 0.1$ & $0.94 \pm .07$ & $0.48 \pm .04$ & $16.0 \pm 0.4$ \\
\hline
\end{tabular}




\title{
APPENDIX A \\ SURVEY PARAMETERS
}

\author{
Survey Site: Wright-Patterson Air Force Base \\ Survey Area: $\quad 64 \mathrm{mi}^{2}\left(165.8 \mathrm{~km}^{2}\right)$ \\ Survey Date: $\quad$ July $7-20,1994$ \\ Survey Altitude: $\quad 150 \mathrm{ft}(46 \mathrm{~m})$ \\ Line Spacing: $\quad 250 \mathrm{ft}(76 \mathrm{~m})$ \\ Line Direction: Southwest/Northeast \\ Line Miles: $\quad 1,352$ \\ Airspeed: $\quad 70$ knots $(36 \mathrm{~m} / \mathrm{s})$ \\ Detector Array: $\quad$ Eight $2-\times 4-\times 16$-in Nal $(\mathrm{Tl})$ detectors \\ Two 2- $\times 4-\times 4$-in $\mathrm{Nal}(\mathrm{Tl})$ detectors \\ Acquisition System: REDAR IV \\ Aircraft: $\quad$ MBB BO-105 Helicopter (N40EG) \\ Project Scientist: $\quad$ E.L. Feimster \\ Data Processing: \\ Man-Made Energy Window: $38-1,394 \mathrm{keV}$ \\ Gross Count Energy Window: $38-3,026 \mathrm{keV}$ \\ Conversion Factor: $1,071 \mathrm{cps}$ per $\mu \mathrm{R} / \mathrm{h}$ \\ Cosmic Ray Contribution: $4 \mu \mathrm{R} / \mathrm{h}$
}




\section{REFERENCES}

1. Boyns, P.K. The Aerial Radiological Measuring System (ARMS): System, Procedures and Sensitivity, (1976). Report No. EGG-1183-1691. EG\&G, Las Vegas, Nevada, 1976.

2. Feimster, E.L. An Aerial Radiological Survey of L Lake and Steel Creek, Savannah River Plant, Date of Survey: July 1986, Report No. EGG-161117-1146. EG\&G/EM, Las Vegas, Nevada, 1986.

3. Mohr, R.A., A.E. Fritzsche, and L.A. Franks. Ground Survey Procedures, Report No. EGG- 1183-2339, S-635-R. EG\&G, Santa Barbara, California, 1976.

4. Quam, W. and K. Engberg. Low Background Ge(Li) Detector with Anticoincidence NaI Annulus, (2nd Revision), Report No. EGG-1183-2326 (Revised), S-628-R. EG\&G, Santa Barbara, California, 1978.

5. Lindeken, C.L., K.R. Peterson, D.E. Jones, and R.E. McMillen. "Geographical Variations in Environmental Radiation Background in the United States," Proceedings of the Second International Symposium on the Natural Radiation Environment, August 7-11, 1972, Houston, Texas. National Technical Information Service, Springfield, Virginia, 1972, pp 317-332. 